\title{
Distribution of Hepatic Myofibroblasts and Type I and III Collagen in Rat Liver Cirrhosis Induced by Thioacetamide
}

\author{
Distribución de Miofibroblastos y Colágeno Tipo I y III \\ en Hígado de Ratas con Cirrosis Inducida por Tioacetamida
}

Raksawan Poonkhum; Wisuit Pradidarcheep; Somneuk Nilbu-Nga \& Suwadee Chaunchaiyakul

POONKHUM, R.; PRADIDARCHEEP, W.; NILBU-NGA, S. \& CHAUNCHAIYAKUL, S. Distribution of hepatic myofibroblasts and type I and III collagen in rat liver cirrhosis induced by thioacetamide. Int. J. Morphol., 29(2):501-508, 2011.

SUMMARY: Thioacetamide (TAA) can induce various types of cirrhosis in the rat, including bridging fibrosis, biliary fibrosis, perisinusoidal/pericellular fibrosis and centrilobular fibrosis, in which different populations of hepatic myofibroblasts (MFs) are involved. The hepatic MFs can be classified into 3 groups: (a) portal/septal MFs; (b) activated hepatic stellate cell myofibroblasts (HSC/MFs); and (c) interface myofibroblasts (IF/MFs). The present study was carried out to examine the morphology and localization of hepatic MFs in relation to the distribution of type I and III collagen in rat cirrhotic livers. Immunohistochemistry to a-smooth muscle actin was employed to demonstrate the morphology and localization of the subpopulations of hepatic MFs. The distribution of type I and III collagen was investigated by using specific antibodies. Portal and septal MFs were windmill in shape and localized around tributaries of the portal and hepatic veins where type I and III collagen was accumulated. HSC/MFs with arachnoid in shape were localized in the spaces of Disse and spaces between neighboring hepatocytes where type I collagen was formed. IF/MFs showed arachnoid shapes and distributed along the margin of fibrous septa where type I collagen was condensed. MFs with polygonal shapes were also found around the wall of hepatic sinusoids, margin of fibrous septa and around the portal tract. They were probably transitional cells to the mature MFs. Our data suggest that each subpopulation of hepatic MFs shows characteristic morphology and localization, which correlates with localization of type I and/or type III collagen.

KEY WORDS: Hepatic myofibroblasts; Type I, III collagens; Thioacetamide; Cirrhosis.

\section{INTRODUCTION}

Cirrhosis is a common end situation of chronic liver inflammation. It is characterized by accumulation of fibrous connective tissue and severe disfigure of pseudolobules. In normal and pathological conditions, major part of fibrous connective tissue in the liver consists of extra-cellular matrix components, including interstitial collagens (type I, III) and basement membrane collagen (type IV) (Maher \& McGuire, 1990; Adachi et al., 1991). There are many experimental models to demonstrate cirrhotic livers such as pyrrolizidine alkaloid lasiocarpine-induced cirrhosis (Reddy et al., 1976), CCl4induced cirrhosis (Martinez-Hernandez, 1985; Dashti et al., 1989), and thioacetamide (TAA)-induced cirrhosis (Dashti et al.; Al-Bader et al., 2000; Sato et al., 2000; Nakata et al., 2002).

Hepatic myofibroblasts (MFs) represent a collective definition for a heterogenous population of profibrogenic cells, mostly positive for a-smooth mucle actin (a-SMA), which can be easily identified in chronically injured livers (i.e., fibrotic or cirrhotic) in either clinical or experimental conditions (Cassiman et al., 2002; Parola et al., 2008; Novo et al., 2009). Concerning their antigen profile and/or tissue localization, at least three different subpopulations of MFs have been described (Cassiman et al.; Cassiman \& Roskams, 2002; Parola et al.): (a) portal/septal MFs, which possess an identical antigen repertoire and can be found either in the inner part of fibrotic septa (septal MFs) or within the expanded portal tracts (portal MFs); (b) activated HSC or HSC/MFs, mainly located in or around capillarised sinusoids of fibrotic/cirrhotic livers; and (c) interface MFs, essentially located at the edge between fibrotic septa and surrounding parenchyma. The different subpopulations of hepatic MFs and the predominant pro-fibrogenic mechanism are involved in the formation of major fibrotic patterns (bridging fibrosis, biliary fibrosis, perisinusoidal/pericellular fibrosis and centrolobular fibrosis) (Cassiman \& Roskams; Pinzani \& Rombouts, 2004; Parola et al.; Povero et al., 2010). 
However, little is known about the relationships between the morphology and localization of hepatic MFs and the distribution of type I and III collagen in main fibrotic patterns of cirrhotic livers. The present study is carried out to elucidate the morphology and localization of subpopulations of hepatic MFs using immunohistochemistry to a-SMA. The distribution of type I and III collagens was also explored by immunohistochemistry.

\section{MATERIAL AND METHOD}

Animal. Ten male Wistar rats weighing between 150-200 $\mathrm{g}$ were used in this study. They were purchased from The National Laboratory Animal Centre (NLAC, Salaya, Thailand). The animals were kept in the room maintained at $25 \mathrm{oC}$ on a 12-hour light/dark cycle and ad libitum to water and food. The rats were administered with TAA for induction of cirrhosis by intraperitoneal injection $(200 \mathrm{mg} /$ $\mathrm{kg}$ ) for 3 times per week for consecutive 12 weeks. After that the rats were euthanized by carbon dioxide or ether inhalation and killed rapidly by decapitation. The rat livers were immediately removed through a midline abdominal wall incision. This study was conducted according to The National Research Council (NRC) guide for care and use of laboratory animals and was approved by the Faculty of Medicine, Srinakharinwirot University Institutional Animal Care and Use Committee (IACUC).

Tissue preparation. The specimens were fixed with $4 \%$ paraformaldehyde for $24 \mathrm{hr}$ at $4^{\circ} \mathrm{C}$. Thereafter, the samples were dehydrated in graded concentrations of ethanol and processed till embedded in paraplast. Serial sections of 5-7 $\mu \mathrm{m}$ in thickness were prepared and mounted on poly Llysine-coated slides. Some of the sections were histologically stained with sirius red in order to identify collagen fibers, the remaining slides were stored at $4 \mathrm{oC}$ for subsequent immunohistochemical analysis.

Procedure for immunohistochemistry. The sections were deparaffinized in xylene, dehydrated and washed in

Table I. Antibodies used.

\begin{tabular}{lccc}
\hline Antibodies & Host & Dilution & Company \\
\hline -SMA & Mouse & $1: 500$ & Chemicon \\
rat-anti collagen type I & Rabbit & $1: 500$ & Chemicon \\
rat-anti collagen type III & Rabbit & $1: 100$ & AbD Serotec \\
GAR-AP & & $1: 200$ & Dako. Inc. \\
GAM-AP & & $1: 200$ & Dako. Inc. \\
\hline
\end{tabular}




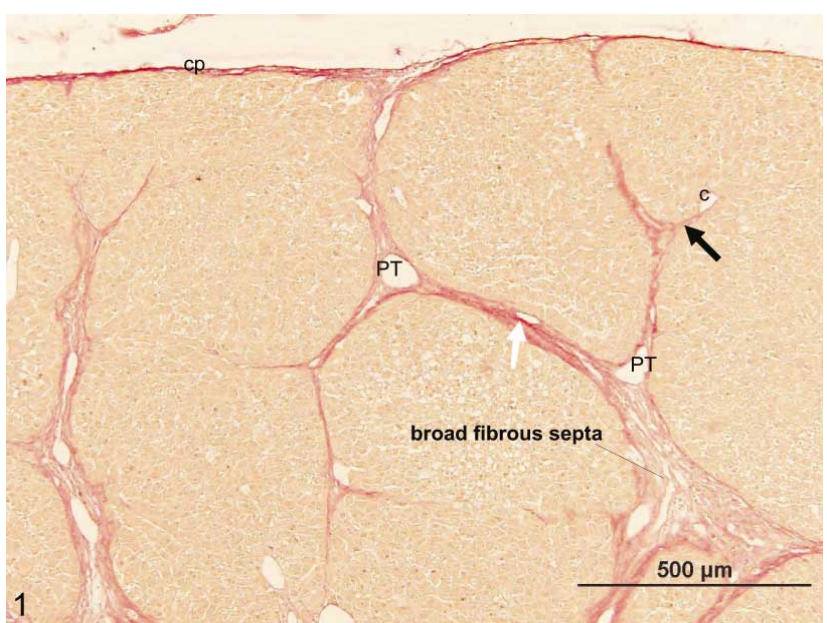

Fig. 1. Porto-portal septa (white arrow) are thicker than porto-central septa (black arrow). Light micrographs of TAA-induced rat liver cirrhosis stained with sirius red.

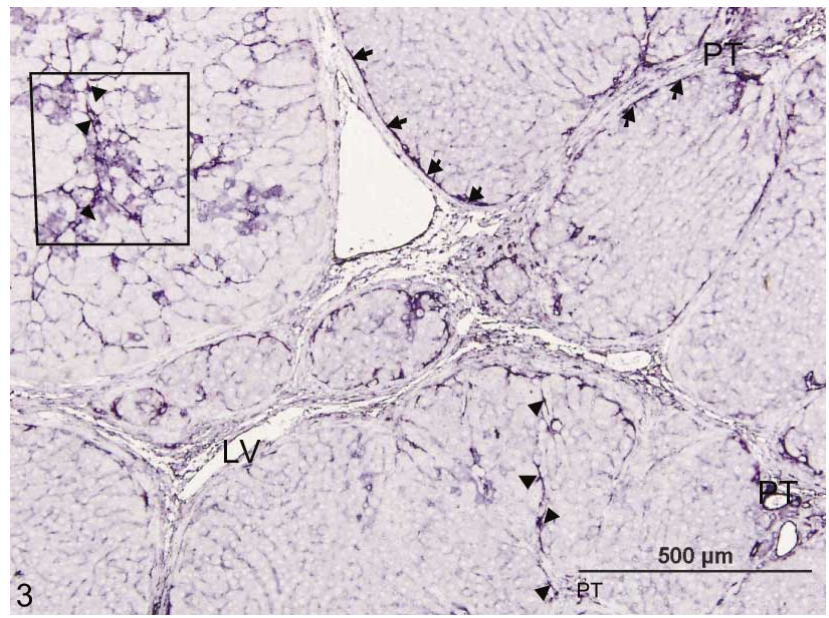

Fig. 3. There are IF/MFs (arrows) at the broad fibrous septa and HSC/MFs (arrowheads) around the hepatic sinusoids and dispersed within the nodules. Immunohistochemistry to a-SMC in TAA-induced rat liver cirrhosis.

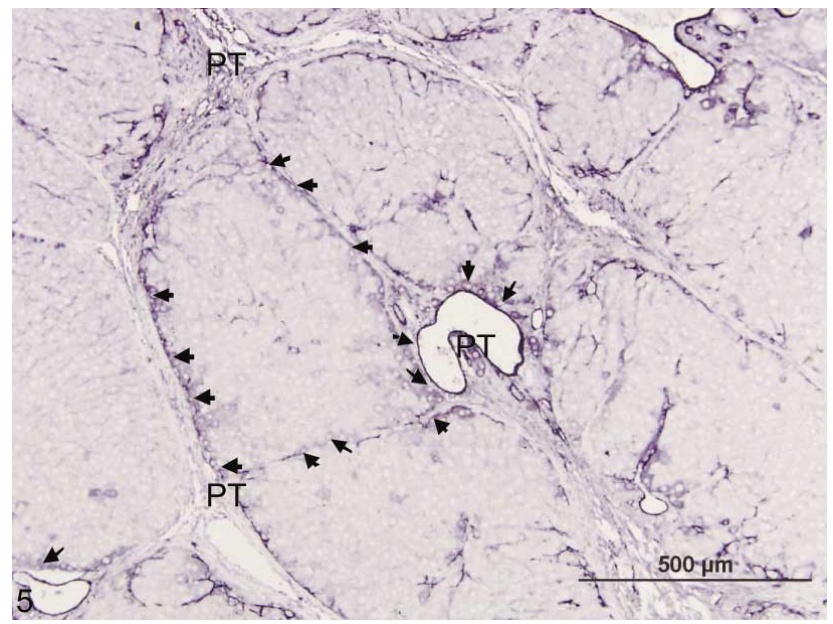

Fig. 5. Transitional cells (arrows) are located at the margin of nodule between parenchyma and broad fibrous septa and in the portal tract (PT). Immunohistochemistry to a-SMC in TAA-induced rat liver cirrhosis.

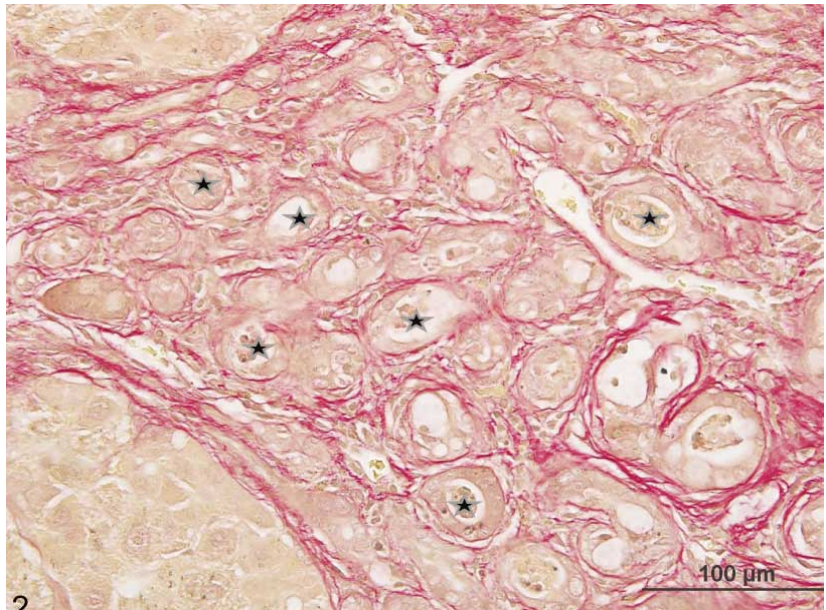

Fig. 2. Extensively proliferated bile ducts (star) can be seen in the portal area. CP: capsule; PT: portal tract; c: cental vein. Light micrographs of TAA-induced rat liver cirrhosis stained with sirius red.

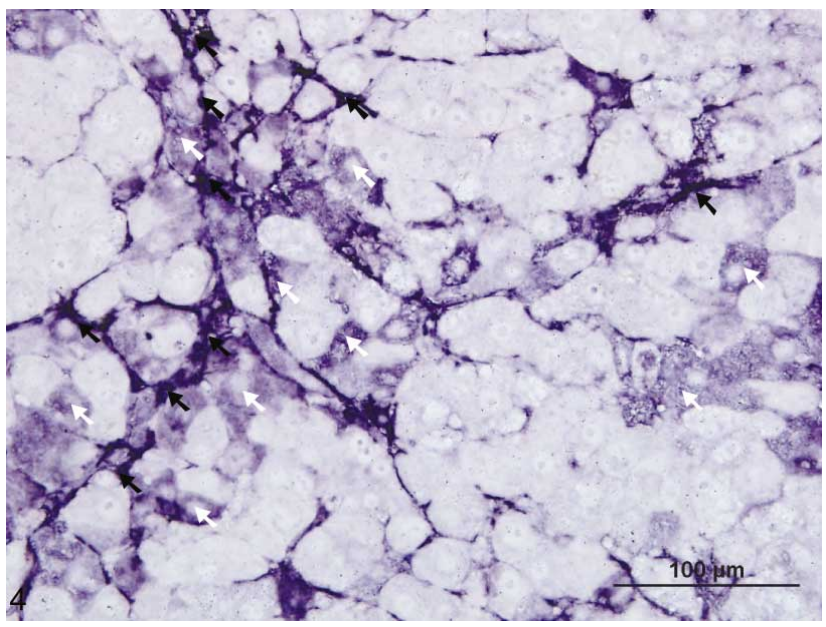

Fig. 4. Higher magnification of figure 3. HSC/MFs (black arrows) with arachnoid shapes are strongly labeled, whereas perisinusoidal transitional cells (white arrows) are polygonal shapes and weakly labeled. Immunohistochemistry to a-SMC in TAA-induced rat liver cirrhosis.

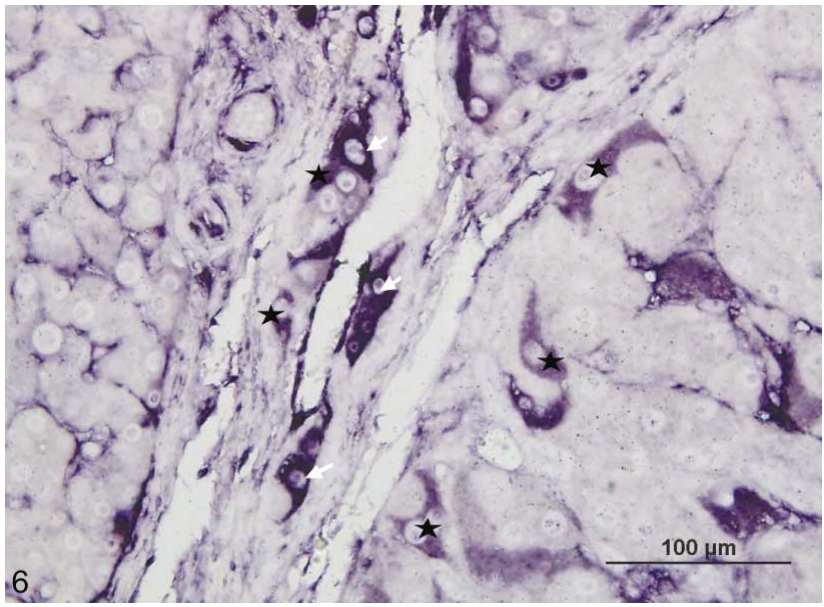

Fig. 6. Septal MFs (white arrows) with windmill shapes and strong labeling can be seen in broad fibrous septa. There are also transitional cells (stars) with polygonal shapes and weak labeling. Immunohistochemistry to a-SMC in TAA-induced rat liver cirrhosis. 


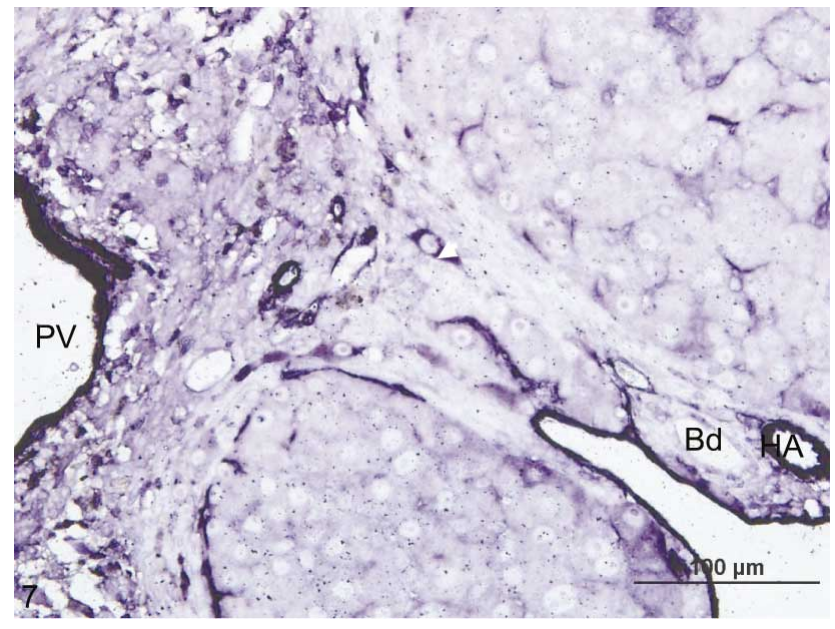

Fig. 7. Potal MFs (white arrows) with windmill shapes can be seen around the portal tract. Immunohistochemistry to a-SMC in TAA-induced rat liver cirrhosis.

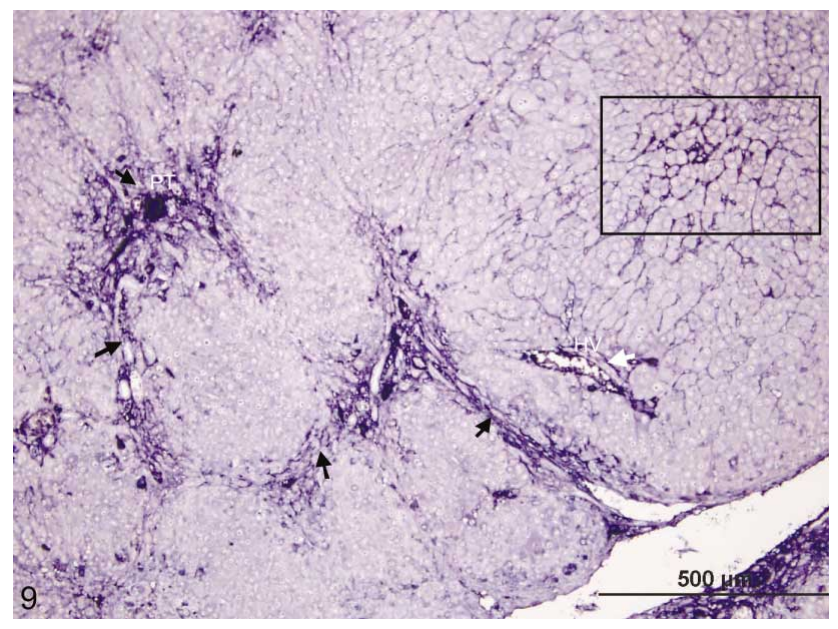

Fig 9. Type I collagen fibers (black arrows) are intensively distributed in broad fibrous septa and around nodules. Nevertheless, type I collagen fibers faintly dispersed around tributaries of hepatic veins (white arrow). Immunohistochemistry to type I collagen in TAA induced rat cirrhotic liver.

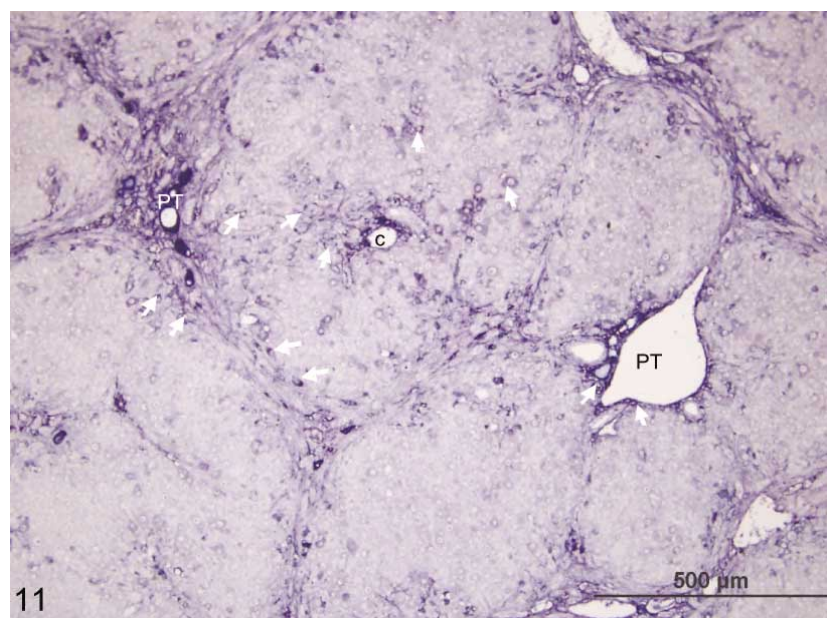

Fig 11. Transitional cells (white arrows) with immunoreactivity for type I collagen can be seen at the margin of septa and around the central vein (c). Some transitional cells observed around portal tract. Immunohistochemistry to type I collagen in TAA induced rat cirrhotic liver.

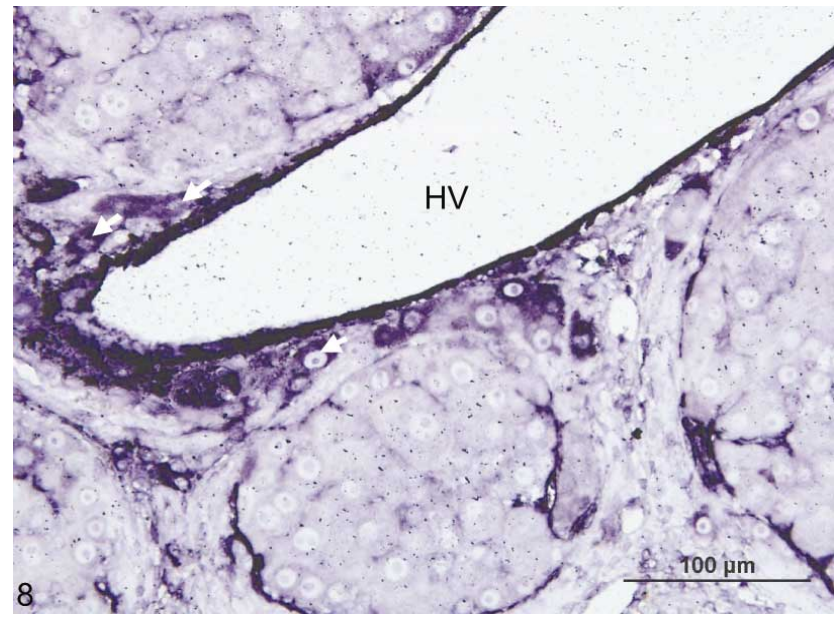

Fig. 8. Central MFs (white arrows) have windmill in shape that located surrounding tributaries of hepatic veins. Bd: bile duct; HA: hepatic artery; HV: hepatic vein; LV: lymphatic vessels; PT: portal tract; PV: portal vein. Immunohistochemistry to a-SMC in TAA-induced rat liver cirrhosis.

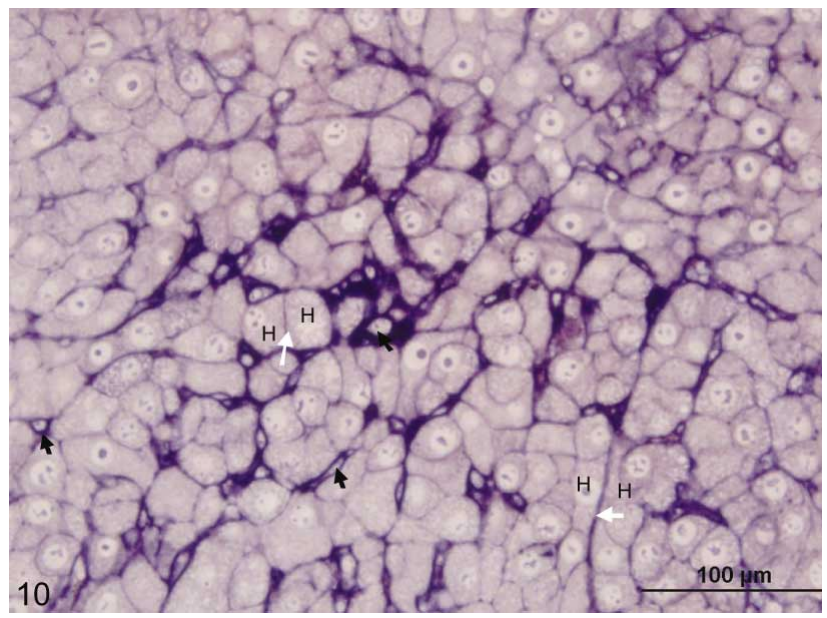

Fig 10. Higher magnification of figure 9. HSC/MFs (black arrows) and type I collagen fibers (white arrow) in the spaces between hepatocytes are labeled in dark blue. Immunohistochemistry to type I collagen in TAA induced rat cirrhotic liver.

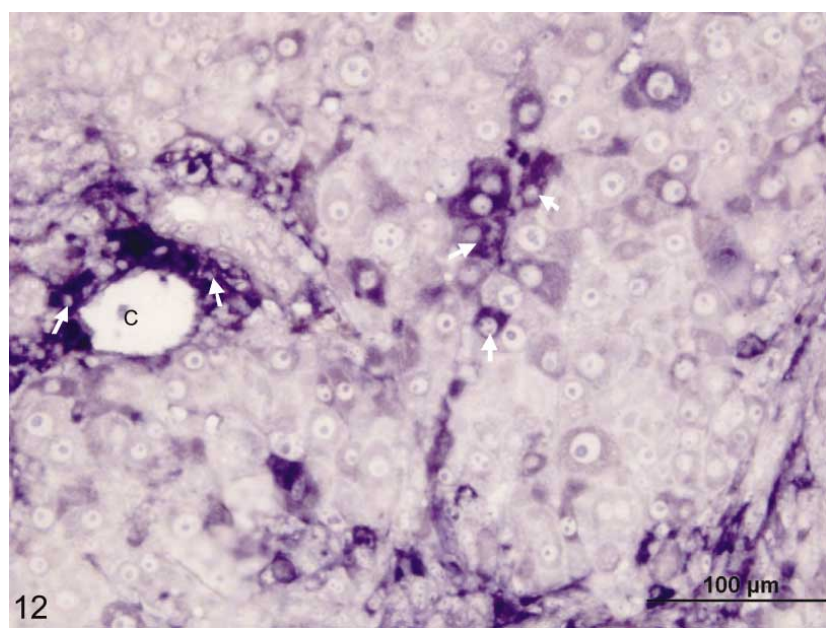

Fig. 12. Higher magnification of Figure 11. Transitional cells (white arrows) are dispersed around central vein and wall of hepatic sinusoid. c: central vein; H: hepatocyte; HV: hepatic vein; PT: portal tract. Immunohistochemistry to type I collagen in TAA induced rat cirrhotic liver. 


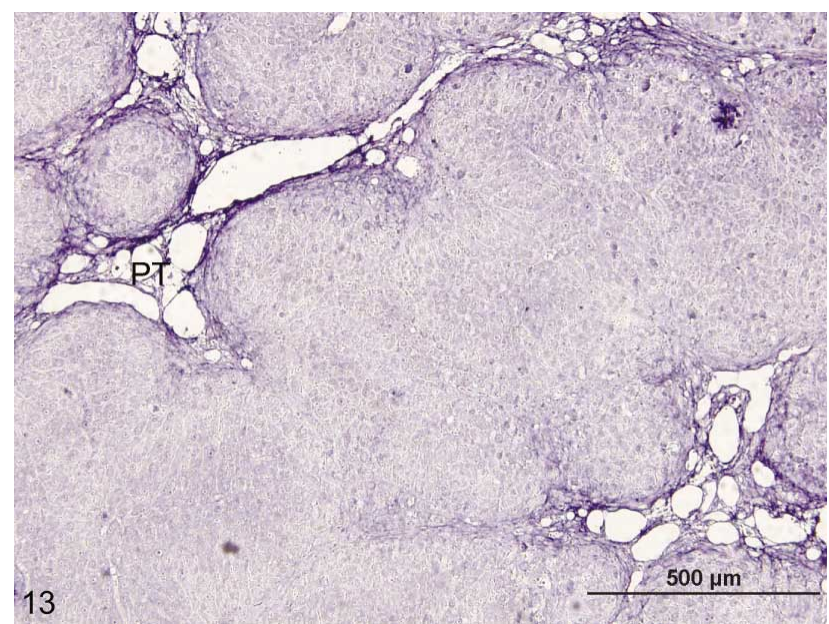

Fig. 13. Vascular walls show labeling of type III collagen. Immunohistochemistry to type III collagen in TAA induced rat cirrhotic liver.

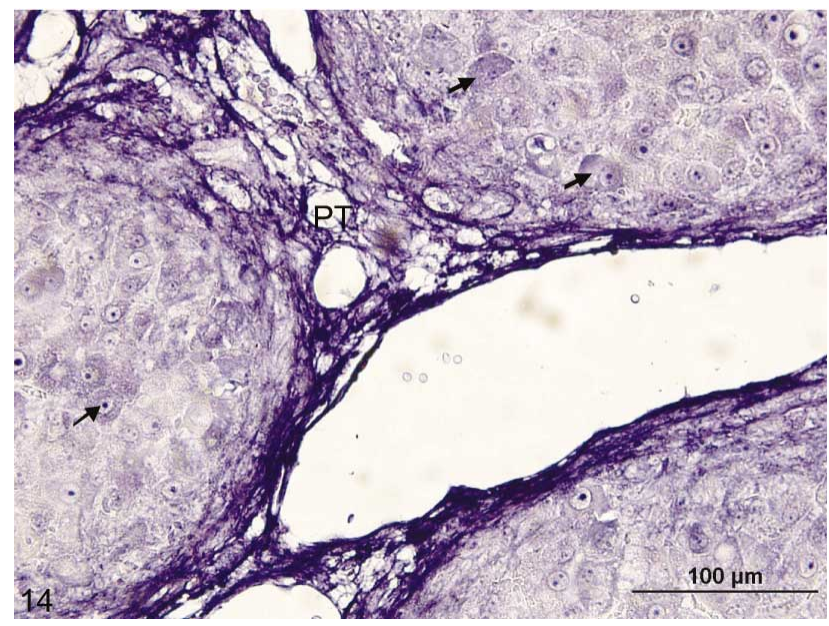

Fig. 14. Higher magnification of figure 13. Type III collagen fibers are accumulated on the vascular wall. Transitional cells (arrows) show positive labeling of type III collagen. PT: portal tract. Immunohistochemistry to type III collagen in TAA induced rat cirrhotic liver.

blue labeling of a-SMA. There was another cell group with paler blue labeling for a-SMA situated near the HSC/MFs. The cells of this group were polygonal in shape (Fig. 4). Some of them were found to adhere to the margins of fibrous septa surrounding nodules and some were found in the portal tract (Fig. 5). Septal MFs resided in the inner part of broad fibrous septa, while portal MFs in the portal area (Figs. $6,7)$. Both of them were windmill in shape and showed dark blue labeling for a-SMA. We named MFs adhering to the wall of tributaries of hepatic veins and appeared dark blue labeling of a-SMA, which has not ever mentioned in the literature, as central myofibroblasts (Fig. 8).

Type I collagen was predominantly distributed in the broad fibrous septa surrounding nodules. Type I collagen accumulation was denser around the portal tract than around the tributaries of hepatic veins (Fig. 9). HSC/MFs and collagen in interhepatocytic spaces also showed immunoreactivity to type I collagen (Fig. 10). MFs with polygonal shapes showed dark blue labeling to type I collagen. They were localized at the margins of septa, around hepatic sinusoids, surrounding portal tract as well as around the central veins (Figs 11 and 12).

Type III collagen was generally restricted around the vascular walls in and around the hepatic nodules (Fig. 13). Type III collagen was also detected in the cytoplasm of the MFs with polygonal shapes located in the inner part of nodules (Fig. 14).

\section{DISCUSSION}

The present study has confirmed that TAA, like CCl4, is a potent inducer for four main fibrotic patterns of cirrhosis in rat, including bridging fibrosis (Park et al., 2010), biliary fibrosis (Müllerad et al., 1996), perisinusoidal/pericellular fibrosis and centrilobular fibrosis (Weber et al., 2003). Our immunohistochemistry to a-SMA has demonstrated subpopulations of hepatic MFs in the cirrhotic livers. The present study has also shown relationships between distribution of subpopulations of MFs and that of type I and III collagen in the TAA-induced cirrhotic liver in the rat.

The present study shows the distinct morphology and localization of the 4 groups of hepatic MFs: portal/septal MFs, central MFs, interface MFs (IF/MFs), and hepatic stellate cell-like MFs (HSC-MFs). Portal/septal MFs are windmill in shape and have been reported to originate from the portal fibroblasts (Parola et al.; Novo et al.; Povero et $a l$.). Central MFs, distributing close to the walls of tributaries of hepatic veins, has similar shape to the portal/septal MFs. IF/MFs and HSC/MFs are arachnoid in shape. IF/MFs are localized at the margin of fibrous septa, whereas HSC/MFs around the wall of hepatic sinusoids.

Based on sequential ultrastructural and immunohistochemical studies, HSC are thought to transdifferentiate to perisinusoidal transitional cells and then on to MF-like cells, following repeated damage to the liver (Kent et al., 1976; Mak \& Lieber, 1988; Schmitt-Gräff et al., 1993). Perisinusoidal and pericellular fibrosis is thought to result from an imbalance between extracellular matrix production and degradation by HSC, perisinusoidal transitional cells and perisinusoidal MF (Cassiman et al.). In addition, the present study has shown MFs (herein termed transitional MFs) with polygonal shapes at around the portal areas as well as in the same regions where septal MFs, 
IF/MFs and HSC/MFs are localized. HSC/MFs derive from HSC (Povero et al.). HSCs in the spaces of Disse are considered to be mesenchymal origin (Sato et al., 2003). These suggest that the perisinusoidal transitional MFs are in the transforming process from HSCs to HSC/MFs. Moreover, Portal fibroblasts are considered to give origin to portal/septal MFs (Novo et al.). Therefore, it is possible that portal transitional cells are in the transforming process from portal fibroblasts to portal/septal MFs.

The fact that type I and III collagen fibers are localized around the portal area suggest that these collagen fibers may be synthesized by the portal MFs. Indeed, both types of collagen fibers show markedly increase around the tributaries of portal veins. On the other hand, HSC/MFs localized in the spaces of Disse and in spaces between adjacent hepatocytes express type I collagen immunoreactivity. Therefore, it is likely that portal MFs contribute to the formation of type I and III collagen fibers around the portal areas, whereas HSC/MFs produce type I collagen fibers that form porto-portal fibrous septa.

Central MFs are localized around the wall of tributaries of hepatic veins where type I and III collagen fibers are accumulated. Although both types of collagen fibers are deposited to some extent around the tributaries of the hepatic veins, they are heavily condensed around the portal tract. These suggest that both central and portal MFs synthesize type I and III collagen fibers and that portal MFs may produce collagen fibers more than central MFs. On the other hand, HSC/MFs in the space of Disse and in space between neighboring hepatocytes express type I collagen immunoreactivity, suggesting that HSC/MFs produce type I collagen fibers that form porto-central fibrous septa. Probably, the process of centro-central fibrosis is similar to that of porto-portal fibrosis, except type I and type III collagen fibers around central veins are produced by central MFs.

Numerous IF/MFs are localized at the margin of broad fibrous septa around nodules. The septa consist of type I collagen fibers. These suggest that IF/MFs synthesize type I collagen fiber for increasing broad fibrous septa. Reportedly, IF/MFs and HSC/MFs play a significant proangiogenic role (Povero et al.). Friedman (2008) states that HSCs in particular play a significant role even in physiological angiogenesis because of their role as liver specific pericytes, which are strategically located in the space of Disse and intimately contact with sinusoids endothelial cells. Morphologically, IF/MFs are similar to HSC/MFs, suggesting that IF/MFs and HSC-MFs perform similar function. IF/MFs originate from progressive recruitment of bone marrow-derived cells (Forbes et al., 2004) like mesenchymal stem cells or HSC (Russo et al., 2006; di Bonzo et al., 2008) and circulating fibrocytes (Kisseleva et al., 2006). The present study has shown interface transitional MFs localized in the same area of the IF/MFs. In this context, the interface transitional MFs are in the transforming process from bone marrow-derived cells or circulating fibrocytes to IF/MFs.

The present study has shown biliary fibrosis with vast proliferation of bile ductules in the portal area. There are no periductular MFs with a-SMA immunoreactivity. Reportedly, a-SMA negative but FSP-1 (fibroblast specific protein type 1) positive MFs may originate from hepatocytes that undergo full epithelial to mesenchymal transition (EMT) program (Zeisberg et al., 2007) and that fibrogenesis may be prevented by treatment with bone morphogenic protein7 (BMP-7), a molecule that has been reported to significantly affect EMT process (Dooley et al., 2008).

HSC/MFs and numerous type I collagen fibers are located in the space of Disse and in space between adjacent hepatocytes. This suggests that HSC/MFs excessively produce type I collagen fibers into these spaces, resulting in perisinusoidal/pericellular fibrosis.

In an experimental model of congestive hepatic fibrosis in rat by legated of vena cava found a large number of a-SMA positive myofibroblasts were observed, and there was heavy deposition of connective tissue proteins, such as reticulin fibers and fibronectin, in centrilobular area (6 weeks after ligation) (Akiyoshi \& Terada, 1999). The present study has shown that central MFs localized around centrolobular vein express type I and III collagen immunoreactivity. Perhaps, central MFs produce type I and III collagen fibers excessively around centrolobular vein, resulting in centrilobular fibrosis. Moreover, MFs located around the centrolobular vein (so-called second-layer cells). They were suggested to proliferate in the livers of alcohol-fed baboons, causing typical 'alcoholic type' of pericentral fibrosis (Nakano \& Lieber, 1982).

In conclusion, the present study has shown that hepatic MFs can be classified into 4 subpopulations: portal/ septal MFs, central MFs, interface MFs (IF/MFs) and HSCMFs. Interestingly, MFs with polygonal shapes were also found around the wall of hepatic sinusoids, margin of fibrous septa, wall of tributaries of hepatic veins and around the portal tract. They were probably transitional cells to the mature MFs. Our data suggest that each subpopulation of hepatic MFs shows characteristic morphology and localization, which correlates with localization of type I and III collagen in bridging, biliary, perisinusoidall/pericellular and centrilobular fibrosis. 
ACKNOWLEDGMENTS. This study was supported by a research grant from Faculty of Medicine,
Srinakharinwirot University under the contract No. 117/ 2551.

POONKHUM, R.; PRADIDARCHEEP, W.; NILBU-NGA, S. \& CHAUNCHAIYAKUL, S. Distribución de miofibroblastos y colageno tipo I y III en hígado de ratas con cirrosis inducida por tioacetamida. Int. J. Morphol., 29(2):501-508, 2011.

RESUMEN: La tioacetamida (TAA) puede provocar diversos tipos de cirrosis hepática en la rata, incluyendo fibrosis en puente, fibrosis biliar, fibrosis perisinusoidal/pericelular y fibrosis centrolobulillar, en los que diferentes poblaciones de miofibroblastos hepáticos (MFs) están involucrados. Los MFs hepáticos se pueden clasificar en tres grupos: (a) MFs portal/ septal; (b) células estrelladas hepática activada miofibroblásticas (HSC/MFs), y (c) miofibroblastos de interface (IF/MFs). El presente estudio se realizó para examinar la morfología y localización de los MFs hepáticos en relación con la distribución de colágeno Tipos I y III en el hígado de ratas cirróticas. Se utilizó inmunohistoquímica de a-actina de músculo liso para demostrar la morfología y localización de las subpoblaciones de MFs hepática. La distribución de colágenos Tipos I y III se investigó utilizando anticuerpos específicos. FMs portales y septales mostraron forma de molino de viento y se localizaron cerca de afluentes de las venas porta y hepática donde los colágenos Tipos I y III se acumularon. HSC/MFs con forma aracnoide se localizaron en los espacios de Disse y los espacios entre hepatocitos vecinos, donde se formó el colágeno Tipo I. IF/MFs mostraron formas aracnoides y se distribuyeron a lo largo del margen de los septos fibrosos donde se condensó el colágeno Tipo I . MFs con formas poligonales también fueron encontrados alrededor de la pared de los sinusoides hepáticos, en el margen de los septos fibrosos y en todo el tracto portal. Probablemente fueron células de transición a los MFs maduros. Nuestros datos sugieren que cada subpoblación de MFs hepáticos muestra una morfología y localización característica, que se correlaciona con la localización de colágenos Tipo I y o III.

PALABRAS CLAVE: Miofibroblastos hepáticos; Colágeno tipo I; Colágeno tipo III; Tioacetamida; Cirrosis.

\section{REFERENCES}

Adachi, E.; Hayashi, T. \& Hashimoto, P. H. A comparison of the immunofluorescent localization of collagen type I, III, and V with the distribution of reticular fibers on the same liver sections of the snow monkey (Macaca fuscata). Cell Tissue Res., 264(1):1-8, 1991.

Akiyoshi, H. \& Terada, T. Centrilobular and perisinusoidal fibrosis in experimental congestive liver in the rat. $J$. Hepatol., 30(3):433-9, 1999.

Al-Bader, A.; Mathew, T. C.; Abul, H.; Al-Sayer, H.; Singal, P. K. \& Dashti, M. H. Cholangiocarcinoma and liver cirrhosis in relation to changes due to thioacetamide. Mol. Cell Biochem., 185(1-2):1-9, 2000.

Cassiman, D.; Libbrecht, L.; Desmet, V.; Denef, C. \& Roskams, T. Hepatic stellate cell/myofibroblast subpopulations in fibrotic human and rat livers. $J$. Hepatol., 36(2):200-9, 2002.

Cassiman, D. \& Roskams, T. Beauty is in the eye of the beholder: emerging concepts and pitfalls in hepatic stellate cell research. J. Hepatol., 37(4):527-35, 2002.

Dashti, H.; Jeppsson, B.; Hägerstrand, I.; Hultberg, B.; Srinivas, U.; Abdulla, M. \& Bengmark, S. Thioacetamide- and carbon tetrachloride-induced liver cirrhosis. Eur. Surg. Res., 21(2):83-91, 1989. di Bonza, L. V.; Ferrero, I.; Cravanzola, C.; Mareschi, K.; Rustichelli, D.; Novo, E.; Sanavio, F.; Cannito, S.; Zamara, E.; Bertero, M.; Davit, A.; Francica, S.; Novelli, F.; Colombatto, S.; Fagioli, F. \& Parola, M. Human mesenchymal stem cells as a two-edged sword in hepatic regenerative medicine: engraftment and hepatocyte differentiation versus profibrogenic potential. Gut, 57(2):223-31, 2008.

Dooley, S.; Hamzavi, J.; Ciuclan, L.; Godoy, P.; Ilkavets, I.; Ehnert, S.; Ueberham, E.; Gebhardt, R.; Kanzler, S.; Geier, A.; Breitkopf, K.; Weng, H. \& Mertens, P. R. Hepatocyte-specific Smad7 expression attenuates TGFbeta-mediated fibrogenesis and protects against liver damage. Gastroenterology, 135(2):642-59, 2008.

Forbes, S. J.; Russo, F. P.; Rey, V.; Burra, P.; Rugge, M.; Wright, N. A. \& Alison, M. R. A significant proportion of myofibroblasts are of bone marrow origin in human liver fibrosis. Gastroenterology, 126(4):955-63, 2004.

Friedman, S. L. Hepatic stellate cells: protean, multifunctional, and enigmatic cells of the liver. Physiol. Rev., 88(1):125-72, 2008.

Kent, G.; Gay, S.; Inouye, T.; Bahu, R.; Minick, O. T. \& Popper, H. Vitamin A-containing lipocytes and formation of type III collagen in liver injury. Proc. Natl. Acad. Sci. USA, 73(10):3719-22, 1976. 
Kisseleva, T.; Uchinami, H.; Feirt, N.; QuintanaBustamante, O.; Segovia, J. C.; Schwabe, R. F. \& Brenner, D. A. Bone marrow-derived fibrocytes participate in pathogenesis of liver fibrosis. J. Hepatol., 45(3):429-38, 2006.

Mak, K. M. \& Lieber, C. S. Lipocytes and transitional cells in alcoholic liver disease: a morphometric study. Hepatology, 8(5):1027-33, 1988.

Martinez-Hernandez, A. The hepatic extracellular matrix. II. Electron immunohistochemical studies in rats with CCl4-induced cirrhosis. Lab. Invest., 53(2):166-86, 1985.

Maher, J. J. \& McGuire, R. F. Extracellular matrix gene expression increases preferentially in rat lipocytes and sinusoidal endothelial cells during hepatic fibrosis in vivo. J. Clin. Invest., 86(5):1641-8, 1990.

Müller, D.; Enderle, G. J.; Löw, O.; Dietze, E. \& Krell, H. Bile ductular proliferation and altered leukotriene elimination in thioacetamide-induced fibrosis of rat liver. J. Hepatol., 25(4):547-53, 1996.

Nakano, M. \& Lieber, C. S. Ultrastructure of initial stages of perivenular fibrosis in alcohol-fed baboons. Am. J. Pathol., 106(2):145-55, 1982.

Nakata, M.; Nakamura, K.; Koda, Y.; Kaminou, T.; Ogami, M. \& Yamada, R. Alterations to hepatic microcirculation in thioacetamide-induced cirrhotic livers of rats. Osaka City Med. J., 48(1):1-8, 2002.

Novo, E.; di Bonzo, L. V.; Cannito, S.; Colombatto, S. \& Parola, M. Hepatic myofibroblasts: A heterogeneous population of multifunctional cells in liver fibrogenesis. Int. J. Biochem. Cell Biol., 41(11):208993, 2009.

Park, S. Y.; Shin, H. W.; Lee, K. B.; Lee, M. J. \& Jang, J. J. Differential Expression of Matrix Metalloproteinases and Tissue Inhibitors of Metalloproteinases in Thioacetamide-Induced Chronic Liver Injury. J. Korean Med. Sci., 25(4):570-6, 2010.

Parola, M.; Marra, F. \& Pinzani, M. Myofibroblast-like cells and liver fibrogenesis: emerging concepts in a rapidly moving scenario. Mol. Asp. Med., 29(1-2):5866, 2008.

Pinzani, M. \& Rombouts, K. Liver fibrosis-from the bench to clinical targets. Dig. Liver Dis., 36(4):231-42, 2004.
Povero, D.; Busletta, C.; Novo, E.; di Bonzo, L. V.; Cannito, S.; Paternostro, C. \& Parola, M. Liver fibrosis: a dynamic and potentially reversible process. Histol. Histopathol., 25(8):1075-91, 2010.

Reddy, J. K.; Rao, M. S. \& Jago, M. V. Rapid development of hyperplastic nodules and cirrhosis in the liver of rats treated concurrently with thioacetamide and pyrrolizidine alkaloid lasiocarpine. Int. J. Cancer, 17(5):621-5, 1976.

Russo, F. P.; Alison, M. R.; Bigger, B. W.; Amofah, E.; Florou, A.; Amin, F.; Bou-Gharios, G.; Jeffery, R.; Iredale, J. P. \& Forbes, S. J. The bone marrow functionally contributes to liver fibrosis. Gastroenterology, 130(6):1807-21, 2006.

Sato, M.; Kakubari, M.; Kawamura, M.; Sugimoto, J.; Matsumoto, K. \& Ishii, T. The decrease in total collagen fibers in the liver by hepatocyte growth factor after formation of cirrhosis induced by thioacetamide. Biochem. Pharmacol., 59 (6):681-90, 2000.

Sato, M.; Suzuki, S. \& Senoo, H. Hepatic stellate cells: unique characteristics in cell biology and phenotype. Cell Struct. Funct., 28(2):105-12, 2003.

Schmitt-Gräff, A.; Chakroun, G. \& Gabbiani, G. Modulation of perisinusoidal cell cytoskeletal features during experimental hepatic fibrosis. Virchows Arch. A Pathol. Anat. Histopathol., 422(2):99-107, 1993.

Weber, L. W.; Boll, M. \& Stampfl, A. Hepatotoxicity and mechanism of action of haloalkanes: carbon tetrachloride as a toxicological model. Crit. Rev. Toxicol., 33(2):10536, 2003.

Zeisberg, M.; Yang, C.; Martino, M.; Duncan, M. B.; Rieder, F.; Tanjore, H. \& Kalluri, R. Fibroblasts derive from hepatocytes in liver fibrosis via epithelial to mesenchymal transition. J. Biol. Chem., 282:23337-47, 2007.

Correspondence to:

Dr. Poonkhum R.

Department of Anatomy

Faculty of Medicine

Srinakharinwirot University

Bangkok

THAILAND

Received: 07-02-2011

Accepted: 14-03-2011

Email: raksawan@swu.ac.th 